\title{
Secang Heartwood Ethanolic Extract (Caesalpinia sappan L.) Inhibits Mesenchymal Stem Cells Senescence
}

\author{
Asri Mega Putri ${ }^{1}$, Nindya Budiana Putri ${ }^{1}$, Rahmawaty Rachmady ${ }^{1}$, \\ Idlohatud Dilalah $^{1}$, Retno Murwanti ${ }^{3}$, Edy Meiyanto ${ }^{1,2 *}$ \\ ${ }^{1}$ Cancer Chemoprevention Research Center, Faculty of Pharmacy, Universitas Gadjah Mada, Indonesia \\ ${ }^{2}$ Department of Pharmaceutical Chemistry, Faculty of Pharmacy, Universitas Gadjah Mada, Indonesia \\ ${ }^{3}$ Department of Pharmacology and Clinical Pharmacy, Faculty of Pharmacy, Universitas Gadjah Mada, Indonesia
}

\begin{abstract}
Antioxidants have the ability to scavenge free radicals, leading to inhibition of cells senescence. Secang Heartwood (Caesalpinia sappan L.) contains flavonoid brazilein, known of its high antioxidant activity. However, the activity of secang as senescent cells inhibitor has not been known. The aim of this study is to explore the potential of Caesalpinia sappan ethanolic extract (CSE) as free radical scavenger, thus inhibits senescent cells. Two concentrations of SE under $\mathrm{IC}_{50}$, $2 \mu \mathrm{g} / \mathrm{mL}, 5 \mu \mathrm{g} / \mathrm{mL}$ and $10 \mu \mathrm{g} / \mathrm{mL}$ were applied on Mesenchymal Stem Cells (MSCs) and combined with $5 \mu \mathrm{M}$ of doxorubicin (Dox) as senescence inductor; both of them were compared with MSCsDox group. X-gal, chromogenic substrate of senescent cells, was given on MSCs, giving blue stain on senescent cells. To explore brazilein mechanism in senescence inhibition, molecular docking using PLANTS on topoisomerase II was performed. MSCs that treated with $10 \mu \mathrm{g} / \mathrm{mL}$ of SE qualitatively showed reduction intensity of blue stain. Number of stained cells also reduced from $76 \%$ of MSCs-Dox to $38 \%$ of $10 \mu g / \mathrm{mL}$ SE-Dox group. Docking score shows that brazilein (-86.9I) is more stable to interact with topoisomerase II than doxorubicin $(-82.46)$ and has same binding site ( $\mathrm{Val}$ 174). These findings demonstrate starting knowledge on CSE potential as senescent cells inhibitor through brazilein activity on topoisomerase II.
\end{abstract}

Keyword: Caesalpinia sappan L., Senescence, B-galactosidase, Molecular Docking

\section{INTRODUCTION}

Free radicals cause problems on cell cycle, induce aging to cells. The unbalance cell cycle caused by free radicals renders the cells entering senescence phase and aging happens (Chretien, et al., 2008). Aging on cells is commonly correlated with senescence phase on cell cycle (Hayflick, 1965). Senescence is a stage on cell cycle where the cells do not grow, but do not set death program either (Shay, et al., 2000). Lots of factors can induce senescence such as stress, free radical, cell growth mutation and oncogene activation (Collado, et al., 2007). Therefore we need solution to scavenge the free radical in order to inhibit senescence in hope of delaying cells aging.

Senescence is the state of irreversible cell cycle arrest, allows cell components to enlarge due activation of growth factors, resulting in cells hypertrophy (Demidenko and Blogosklonny, 2008). Theoretically, this hypertrophy can be limited with lysosomes activation which explains the elevation of senescence-associated $\beta$-galactosidase (SA $\beta$-Gal) in senescent cells (Kurz, et al., 2000). Activity of SA $\beta$ Gal can be detected in $\mathrm{pH}$ 6, makes it a good marker for cells aging when reacted with chromogenic substrate X-Gal (5-bromo-4-chloro-3-indolyl P3-Dgalactoside), resulting in blue stain on senescent cells (Dimri, et al., 1995; van der Loo, et al., 1998).

A proposal to answer aging problem through senescent cells is by using antioxidant agent, which is commonly known for its activity in scavenging free radical. One of Indonesian plants that have been studied for its antioxidant activity is secang or Sappan wood (Caesalpinia sappan L.). Flavonoids contained in secang, such as brazilin and brazilein, have higher antioxidant activity than BHA and BHT (Lim, et al., 1997) thus can scavenge free radical (Shahidi, 1996). This study aims to know anti-aging potency of secang as senescence inhibitor on cells by using SA $\beta-G a l$ as marker, known as senescenceassociated $\beta$-galactosidase assay (SA $\beta$-Gal assay).

$\overline{\text { *Corresponding author e-mail: edy_meiyanto@ugm.ac.id }}$ 
In this study, SA $\beta$-Gal assay was done in vitro using Mesenchymal Stem Cells (MSCs) as cell model, chosen to minimize cells that naturally and uncontrollably go to senescence phase. MSCs commonly isolated from bone marrow of femur or tibia (Bersenev, 2011). According to study done by Cipriani, et al. (2013), doxorubicin can be used as senescence inductor on MSCs using SA $\beta$-Gal assay. Doxorubicin induces oxidative stress, initiates DNA damage and activates p53 that degrades topoisomerase II expression and leads cells to senescence phase (Gewirtz, et al., 2008; Wang, et al., 1997). Therefore, molecular docking using PLANTS software was also done to know the interaction of secang component and topoisomerase II to inhibit senescence on cells. The objective of this study is to explore the potency of Secang Heartwood or Caesalpinia sappan L. ethanolic extract (CSE) as anti-aging agent through its activity on inhibiting senescent cells.

\section{MATERIALS AND METHODS}

\section{Extract Preparation and Thin Layer Chromatography}

Secang heartwood powder (Caesalpinia sappan L.) was collected from BP2T2OOT, Tawangmangu, Jawa Tengah and determined in the Laboratory of Pharmacognosy, Biology Department, Faculty of Pharmacy Universitas Gadjah Mada. Extraction was done in CCRC Laboratory, Faculty of Pharmacy, Universitas Gadjah Mada. $500 \mathrm{~g}$ of secang heartwood powder was macerated with ethanol $70 \%$ for $5 \times 24$ hours and remacerated for $3 \times 24$ hours in isolated Erlenmeyer glass. The extract was filtrated and concentrated with vacuum rotary evaporator (Indonesian Ministry of Health, 2010). Then, flavonoid contained in secang was identified with Thin Layer Chromatographhy (TLC), using ethyl acetate: toluene: acetic acid glacial (7:3:1 $\mathrm{v} / \mathrm{v} / \mathrm{v}$ ) as mobile phase and silica gel $60 \mathrm{~F} 254$ as stationary phase (Rachmady, 2015). The bands appeared in silica gels between CSE and standard (brazilin, brazilein) were compared and hRf was calculated using:

$$
\mathrm{hRf}=\frac{\text { band range }(\mathrm{cm})}{\text { elution range }(\mathrm{cm})} \times 100
$$

Same bands hRf and color in CSE and standard shows probability of same compounds contained.

\section{Cells Preparation}

12-14 weeks-old female Sprague-Dawley mouse was euthanized with ether, and then the mouse was dissected with sterilized surgical tools. Femur and tibia of the mouse were collected and coated with gauze dampened with $\mathrm{NaCl} 0.9 \%$ and aluminum foil. After that, bone marrow from femur and tibia were isolated under laminar air flow (LAF), and then collected in sterilized conical tube with DMEM Hi Glucose medium and $15 \%$ fetal bovine serum (FBS). The conical tube was centrifuged $400 \mathrm{rpm}, 4^{\circ} \mathrm{C}$ for 10 minutes. Supernatant was discarded, then $8-10 \mathrm{~mL}$ medium was added and suspended. Cells were transferred in tissue culture dish (TCD), added fungizone and penicillin-streptomycin, after that incubated in $37^{\circ} \mathrm{C}$, $5 \% \quad \mathrm{CO}_{2}$. Medium change was done when approximately $10 \%$ of cells were attached in TCD.

\section{MTT Assay}

Concentration of CSE and Dox for senescence assay was known through MTT assay. Cells were distributed in 96 well plate with number of cells 10000 cells per well (Mosmann, 1983) and incubated with various concentration of CSE from range 1 to $1000 \mu \mathrm{g} / \mathrm{mL}$ using DMSO as solvent for 24 hours. Medium was discarded from well plate, after that PBS was used for washing the wells. In the end of incubation, $100 \mu \mathrm{L}$ MTT reagent was added in each well, then incubated for 4 hours in $37^{\circ} \mathrm{C}$ until formazan crystal was formed. Viable cells expressed enzyme that reduced MTT reagent into purple formazan crystal. After 4 hours, stopper reagent consists of SDS $10 \% 100$ was added in each well then incubated in room temperature. The absorbance was read using ELISA reader on $595 \mathrm{~nm}$ wavelength. Absorbance data was conversed in \% viable cell and analyzed statistically using correlation method followed by significance test of $\%$ viable cell. Then, $\mathrm{IC}_{50}$ was calculated using $\log$ probe method to get linearity of log concentration with $\%$ viable cell.

\section{Senescence Assay}

Senescence inhibition assay was done using various concentrations from MTT assay. These various concentrations were taken under $\mathrm{IC}_{50}$ so it won't cause cytotoxicity to the cells. Observation of senescence inhibition was done by culturing MSCs on TCD, after confluent (80\%) cells were cultured in 
6 well plate with DMEM Hi Glucose medium. Cells were incubated for 24 hours, then treated with Doxorubicin as senescence inducer to the cells for another 24 hours. Then, cells were treated with sample CSE by the chosen concentration from MTT assay and incubated for 24 hours. Cells then washed with PBS and added with fixation solution (2\% formaldehyde, $0.2 \%$ glutaraldehyde), then incubated for 5 minutes on $25^{\circ} \mathrm{C}$. Next, washed it with PBS and stained $(40 \mathrm{mM}$ citric acid or sodium phosphate buffer, $5 \mathrm{mM} \mathrm{K}_{4}\left[\mathrm{Fe}(\mathrm{CN})_{6}\right], 150 \mathrm{mM} \mathrm{NaCl}, 2 \mathrm{mM}$ $\mathrm{MgCl}, 1 \mathrm{mg} / \mathrm{mL} \mathrm{X-Gal,} \mathrm{aquadest)} \mathrm{for} \mathrm{12-16} \mathrm{hours}$ on $37^{\circ} \mathrm{C}$. After that, the cells were observed by using microscope (Chainiaux, et al., 2009). Senescent cells showed more intense blue stain from X-Gal substrate. The color intensity was compared qualitatively and the number of stained cells were counted and compared for each treatment and control group.

Senescent cells can be quantified by counting number of cells through digital image-processing tools in situ with Mathlab Tool at least 40 hours after staining (Shlush, et al., 2011). However, in this study quantification of senescent cells were done by calculating $\%$ number of stained cells.

$$
\% \text { stained cells }=\frac{\text { number of stained cells } \mathrm{x} 100 \%}{\text { number of cells observed }}
$$

\section{Molecular Docking}

Target protein files of Topoisomerase II were prepared using YASARA program. The structure of brazilein as ligand was made by using MarvinSketch. Molecular docking was done by using PLANTS software program. Before docking, method validation was chosen by RMSD (Root Mean Square Distances), where RMSD value of heavy atom (ligand) with ligand copy was less than 2 Á shows the method was valid. Then, ligand docking was done and we compared it with the score we got from target protein and origin ligand complex and with score docking from target protein and brazilein (Purnomo, 2011). Lower docking score shows more stabilized bond of ligand and protein.

\section{RESULTS}

\section{Identification of CSE Phytochemical Content}

Determination on sample showed the sample used was secang, with extract yield $23 \% \mathrm{w} / \mathrm{w}$ and TLC identifed flavonoid compounds in CSE were brazilin and brazilin with hRf of 68 on brazilin and 78 on brazilein. Although the mobile phase used in the extraction showed bands of CSE components and it showed probability of the compounds contained in CSE were brazilin and brazilein, further standardization on extraction and TLC method, especially on mobile phase optimization, is still needed in order to really shows clear band separation between compounds (Fig. 1).

\section{Cytotoxic Activity}

Mesenchymal stem cells (MSCs) were isolated from femur and tibia of Sprague-Dawley mouse and harvested after approximately $80 \%$ confluent. MTT assay was used in order to know concentration of CSE and Doxorubicin needed in senescence assay or SA $\beta$-Gal assay MTT assay result shows $\mathrm{IC}_{50}$ of CSE $55 \mu \mathrm{g} / \mathrm{mL}$, while $\mathrm{IC}_{50}$ of doxorubicin was unknown because concentration of doxorubicin that can inhibit 50\% viable cells could not be approached. So, based on previous studies about senescence assay using doxorubicin as senescence inducer, $5 \mu \mathrm{M}$ of doxorubicin was used in this study (Fig 2).

$$
\mathrm{S}=\text { Sampel; } \mathrm{B}=\text { Brazilin; } \mathrm{Br}=\text { Brazilein }
$$

Figure I. TLC Result. (a) Visible light observation (b) observation from UV $254 \mathrm{~nm}$, and (c) observation on 366nm. Red boxes ( ) showed same hRf on sample (S) with brazilin (B) 68 and brazilein $(\mathrm{Br}) 78$. 

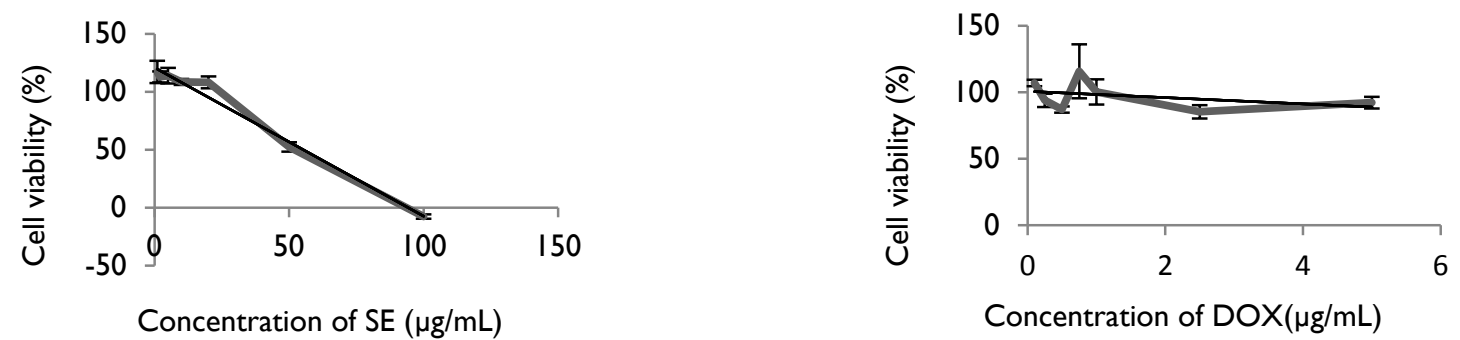

Figure 2. MTT assay result (a) SE treatment on MSCs and (b) Doxorubicin treatment on MSCs viability. Parameter used is $I C_{50}$. Results show dependent dose in CSE and MSCs cell viability $(n=2)$ with $I_{50}$ of $55 \mu \mathrm{g} / \mathrm{mL}$.

\section{Senescence Activity}

The aim was to get the result of senescence inhibition by CSE on MSCs that had been induced with Doxorubicin. Based on MTT assay, $\mathrm{IC}_{50}$ value of CSE is $55 \mu \mathrm{g} / \mathrm{mL}$. Therefore, concentrations under $\mathrm{IC}_{50}$ were chosen in order to keep cells viable and senescence is inhibited. In this study, CSE concentrations $2 \mu \mathrm{g} / \mathrm{mL}, 5 \mu \mathrm{g} / \mathrm{mL}$ and $10 \mu \mathrm{g} / \mathrm{mL}$ are chosen. There are also negative control group and group of cells treated with Doxorubicin. Theoretically, Doxorubicin induces senescence on cells, so SA $\beta$-Gal on cells are expressed and specifically reacted with $\mathrm{X}-\mathrm{Gal}$ substrate on $\mathrm{pH} 6$ resulting blue stain on cells. Results of this study showed that qualitatively, Doxorubicin group gave more intensity of blue color than group treated with CSE, and negative control did not show any blue stain which showed that this group gives most minimum senescent cells (Fig 3). The intensity of blue stain reduced along with the increasing of CSE intensity. Group with CSE $10 \mu \mathrm{g} / \mathrm{mL}$ gave the least intensity than 2 and $5 \mu \mathrm{g} / \mathrm{mL}$. However, cells cultured with Doxorubicin did not give proper cells viability compared to negative control cells. Although senescent cells can still be observed, population of cells treated with Doxorubicin is less than expected.

Number of cells stained with X-Gal substrate was counted from 3 fields of views by microscopy. Then, $\%$ stained cells was calculated. Significance of each group was known statistically with SPSS one way ANOVA. Quantification result showed \% stained cells decreased in CSE treated group than Dox treated group. \% stained cells of Dox group was $76 \%$, negative control group $1.8 \%$, CSE $2 \mu \mathrm{g} / \mathrm{mL}$ $59 \%$, CSE $5 \mu \mathrm{g} / \mathrm{mL} 48 \%$ and CSE $10 \mu \mathrm{g} / \mathrm{mL} 38 \%$ (Fig 4).

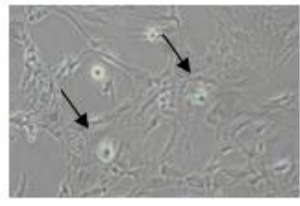

(a)

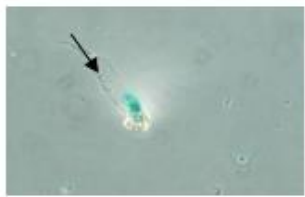

(d)

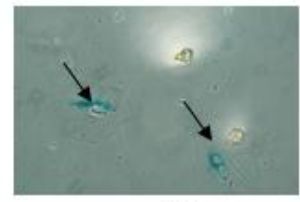

(b)

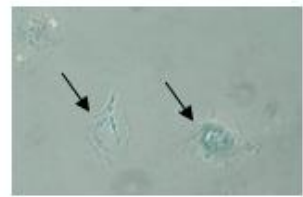

(e)

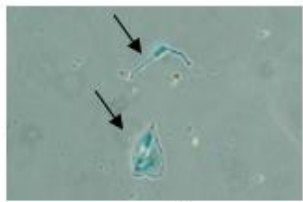

(c)

Figure 3. Senescence Inhibition on MSCs. (a) Negative control, (b) Dox $5 \mu M$, (c) Dox $5 \mu M+C S E 2 \mu g / m L$, (d) Dox 5 $\mu \mathrm{M}+$ CSE $5 \mu \mathrm{g} / \mathrm{mL}$ and (e) Dox $5 \mu \mathrm{M}+$ Dox $10 \mu \mathrm{g} / \mathrm{mL}$. Arrows $\rightarrow$ shows senescent cells with blue stain. 


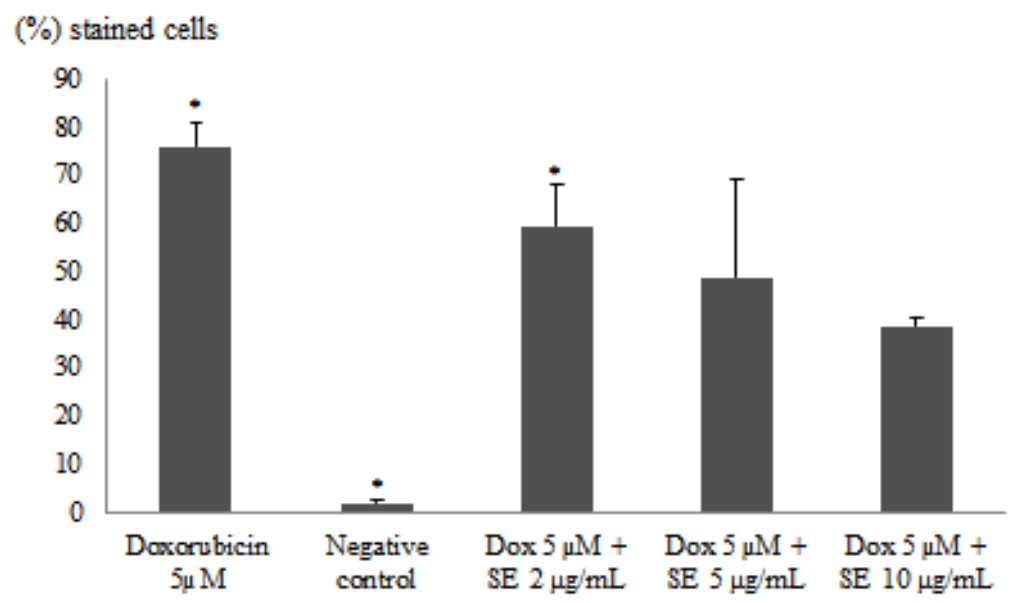

Figure 4. Number of cells stained. \% stained cells by X-Gal substrate decreased along with increasing of CSE concentration. Lower \% stained cells showed less senescent cells. $\left(^{*}\right)$ showed $p<0.05$

\section{Molecular Docking}

Molecular docking was done in silico using YASARA for preparation and PLANTS software, to know interaction of brazilein contained in CSE on Topoisomerase II (PDB ID: 4LPB). RMSD value of $1.10 \AA$ Anowed that molecular docking method was validated. Molecular docking on Topoisomerase enzyme showed brazilein docking score (-86.91) was lower than Doxorubicin (-82.46) (Table 1).

The lower docking score, more stable interaction of ligand and protein. These showed that interaction of brazilein and Topoisomerase II was more stable than interaction of Dox and Topoisomerase II on Val 174 (Fig 5).

Table I. Molecular Docking Result. Docking score of Topoisomerase II with Brazilein and Doxorubicin

\begin{tabular}{cc}
\hline $\begin{array}{c}\text { Docking Score of Topoisomerase II (4LPB) with Brazilein, } \\
\text { Doxorubicin and Ligand Native }\end{array}$ \\
\hline RMSD & $1.10 \AA$ \\
Brazilein & -86.91 \\
Doxorubicin & -82.46 \\
Ligand Native & -103.09
\end{tabular}



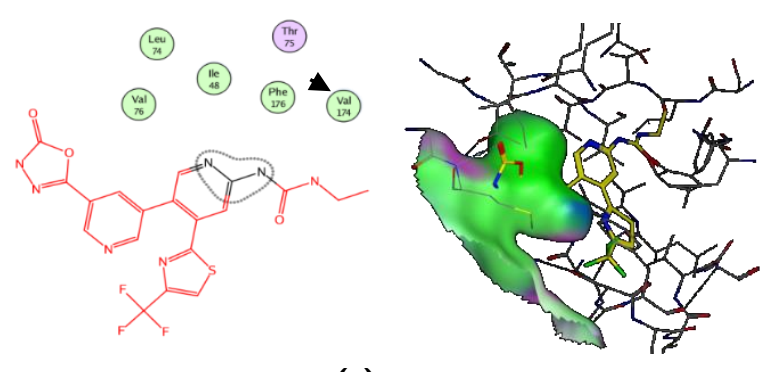

(a)
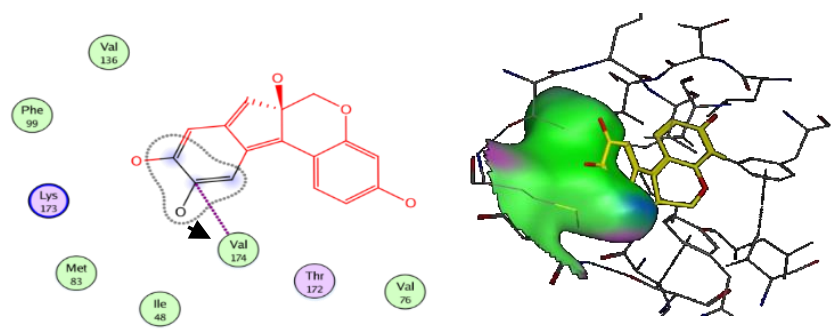

(b)

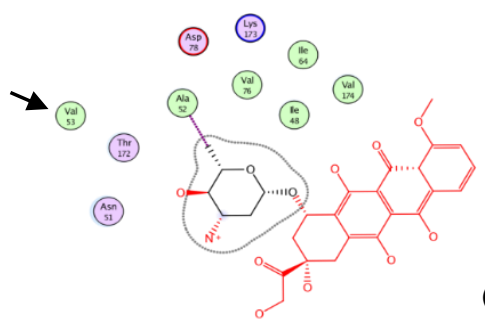

(c)

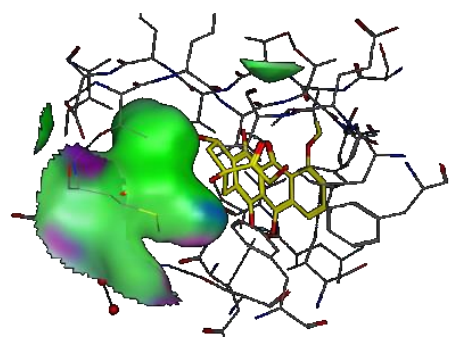

Figure 5. 2D and 3D Visualization of Ligand interaction on Topoisomerase II. Interaction on ligand binding site on Topoisomerase II with (a) native ligand, (b) brazilein,and (c) Doxorubicin. Arrow ( $\rightarrow$ ) shows similar amino acid residue on binding site Valine (Val) 174.

\section{DISCUSSION}

The aim of this study is to know potency of secang heartwood ethanolic extract to inhibit senescence on mesenchymal stem cells by using Doxorubicin as senescence inhibitor on cells. Ethanol $70 \%$ was used in order to extract active components as desired, prevent toxicity on cells and collect bigger yield of extract. Components contained in secang ethanolic extract were identified using thin layer chromatography (TLC) with brazilin and brazilein as standard. TLC result showed secang extract contained same hRf and bands color as brazilin and brazilein, where there were 2 red-brown bands on visible light, muffled color in UV 254 and green fluorescence on UV 366. This showed probability of secang contains brazilin and brazilein. However, standardized method of extraction and TLC is needed to get more validated result.
MSCs were collected from bone marrow of femur and tibia Sprague-Dawley mouse. Although the method of culturing MSCs was done according to previous studies and cells morphology were observed by microscopy, further studies on how to confirm the cells cultured really were MSCs were needed, whether it is by exploring the cells protein expression or other observations. MTT assay was done to get concentration of CSE and Dox used in SA $\beta$-Gal assay. Principle of this assay is calculating cell viability through MTT reagent reduction by succinate dehydrogenase enzyme on viable cells, causing change from yellow color to purple formazan crystal. This purple intensity was counted with ELISA reader $\lambda 595 \mathrm{~nm}$. IC IC $_{50}$ of CSE $55 \mu \mathrm{g} / \mathrm{mL}$ then can be reference to decide concentration for SA $\beta$-Gal assay, $2 \mu \mathrm{g} / \mathrm{mL}, 5 \mu \mathrm{g} / \mathrm{mL}$ and $10 \mu \mathrm{g} / \mathrm{mL}$. On the other hand, Dox $\mathrm{IC}_{50}$ was unable to be calculated. Study from Buttiglieri, et al. (2011) shows $100 \mathrm{nM}$ 
Dox can induce senescence with $80 \%$ of cells viability. Meanwhile, in this study $5 \mu \mathrm{M}$ of Dox gave more than $80 \%$ of cells viability. Therefore, 5 $\mu \mathrm{M}$ of Dox was chosen for SA $\beta$-Gal assay. In Fig. 2 , more than $100 \%$ of cell viability showed bigger absorbance value on treated cells, which gave probability of cell over proliferation.

SA $\beta$-Gal assay was done to identify senescence on cells. Qualitative result of this assay showed Dox treated group gives most intensive blue stain than other groups. Low concentration of Dox inhibits Topoisomerase II activation that leads DNA strain to break and telomere shorting through p53 phosphorylation (Buttiglieri, et al., 2011). Activation of p53 inhibits retinoblastoma protein (pRB) activation and lead cells to senescence phase (Becker and Rizos, 2003). This growth arrest makes senescent cells contain high growth factor leads to the cell hypertrophy, which one of the reasons is caused by over expression of lysosomal enzyme such as $\beta$-galactosidase. On senescent cells, this enzyme reacts specifically with $\mathrm{X}$-Gal substrate in $\mathrm{pH}$ 6, which can be visualized as blue stain by microscopy. Non-senescent cells can also show same result when reacted in $\mathrm{pH} 4$.

In this study, lowest stain intensity was shown in group of cells treated with CSE $10 \mu \mathrm{g} / \mathrm{mL}$ than other CSE treated group. However, cells population on group treated with Dox gave insufficient population of cells. There were several possibilities, but one factor that might lead to this result was unsuitable concentration of Dox as senescence inducer because of unrepresentative concentration profile on MTT assay. Low concentration of Dox induces senescence, however higher concentration of Dox treatment induces death-inducing caspase enzyme, resulting in cell death (van Epps, 2015). Therefore, optimization of Dox concentration on further study is needed to get more representative results.

Molecular docking results showed interaction on Topoisomerase II (PDB ID: 4LPB) -which plays a role on cells senescence, with brazilein contained in secang scored lower (-86.91) than Doxorubicin (-82.46). This result means that doxorubicin, brazilein were stable to interact with Topoisomerase II. How ever interaction of Topoisomerase II with native ligand is more stable than brazilein. Interestingly, visualization of the interaction showed similar binding site of native ligand and brazilein on
Topoisomerase II at Valine residue (Val) 174 (Fig. 5). Further observation and study in this computerized method is needed, especially about the other compounds of secang, such as brazilin, in order to extend more knowledge on secang mechanism on inhibiting senescence on cells.

CSE can be a potential agent to inhibit senescence on MSCs. Active compounds on secang such as brazilein and brazilin which have antioxidant activity most probably play a big role in secang activity on cells senescent inhibition. However, there are still ways to go to explore more about the mechanism of CSE to inhibit senescence and to develop this research to be products that can be used for human in the future.

\section{CONCLUSION}

CSE can inhibit senescence in cells through SA $\beta$-Gal Assay determined by the decreasing of blue intensity in cells which caused by degradation of $\beta$-Gal enzyme expression. By way of molecular docking, brazilein and Topoisomerase II was more stable than interaction of Dox.

\section{ACKNOWLEDGMENT}

The paper was improved for publication by Hilyatul Fadliyah, S.Farm. Appreciation and gratitude are given to DP2M DIKTI that has been funding this research through PKM 2014.

\section{REFERENCES}

Becker, T.M. and Rizos, H., 2003, Regulation of Cellular Senescence by the Retinoblastoma Pathway. In: Kaul S.C. and Wadhwa R.,editor, Aging of Cells in and Outside the Body, Biology of Aging and its Modulation, Vol 2. Dordrecht: Springer.

Bersenev, A., Cell therapy clinical trials in 201I, http://hematopoiesis.info/2012/01/04/celltherapy-trials-20II, Cited February 12, 2016.

Buttiglieri, S., Ruella, M., Risso, A., Spatola, T., Silengo, L., Avvedimento, E.V., et al., 20II, The Aging Effect of Chemotherapy on Cultured Human Stem Cells, Exp. Hem., 39(I2), || $|7|-|| 8 \mid$. 
Chainiaux, F. D., Jorge, D.E., Judith, C. and Oliver, T., 2009, Protocols to Detect Senescenceassociated Beta-galactosidase (SA-Bgal) Activity, A Biomarker of Senescent Cells in Culture and in vivo, Nat. Pub. Group, 4(12), 1798-1804.

Cipriani, P., Di Benedetto, P., Liakouli, V., Del Papa, B., Di Padova, M., Di lanni, M., et al., 2013. Mesenchymal Stem Cells (MSCs) from Scleroderma Patients (SSc) Preserve Their Immunomodulatory Properties Although Senescent and Normally Induce T Regulatory Cells (Tregs) with a Functional Phenotype: Implications for Cellular-based Therapy, Clin. Exp. Immunol., I 73(2), 195-206.

Collado, M., Blasco, M.A. and Serrano, M., 2007, Cellular Senescence in Cancer and Aging, Cell, I30(2), 223-233.

Demidenko, Z.N. and Blagosklonny, M.V., 2008, Growth Stimulation Leads to Cellular Senescence When the Cell Cycle is Blocked, Cell Cycle, 7(2I), 3355-336I.

Departemen Kesehatan RI, 2010, Suplemen I Farmakope Herbal Indonesia, Jakarta: Departemen Kesehatan RI.

Dimri, G. P., Lee, X. and Basile, G., 1995., A Biomarker that Identifies Senescent Human Cells in Culture and in Aging Skin in vivo, Cell Biol., 92, 9363-9367.

Gewirtz, D.A., 1999, A Critical Evaluation of the Mechanisms of Action Proposed for the Antitumor Effects of the Anthracycline Antibiotics Adriamycin and Daunorubicin, Biochem. Pharmacol., 57(7), 727-74I.

Gewirtz, D.A., Holt, S.E. and Elmore, L.W., 200, Accelerated Senescence: An Emerging Role in Tumor Cell Response to Chemotherapy and Radiation, Biochem. Pharmacol., 76(8), 947957.

Hayflick, L., 1965, The Limited in vitro Lifetime of Human Diploid Cell Strains, Exp. Cell. Res., 37(3), 614-636.

Heyne, K., 1987, Tumbuhan Berguna Indonesia, Jilid II, Jakarta: Departemen Kehutanan Republik Indonesia.

Khamsita, R., Hermawan, A., Putri, D. and Meiyanto, E, 2012, Ethanolic Extract of Secang
(Caesalpinia sappan L.) Wood Performs as Chemosensitizing Agent through Apoptotic Induction on Breast Cancer MCF-7 Cells, Indones. J. Cancer Chemoprevent., 3(3), 444449.

Larsen, A.K., Escargueil, A.E. and Skladanowski, A., 2003, From DNA Damage to G2 Arrest: The Many Roles of Topoisomerase II, Prog. Cell Cycle Res, 5, 295-300.

Lawless, C., Wang, C., Jurk, D., Merz, A., von Zglinicki, T., Passos, J.F. 2010. Quantitative Assessment of Markers for Cell Senescence, Exp. Ger., 45(10), 772-778.

Lim, D.K., Choi, U. and Shin, D.H., 1997, Antioxidative Activity of Some Solvent Extract from Caesalpinia sappan Linn, Korean J. Food Sci. Technol., 28(I), 77-82.

Meirelles, L.D.S. and Nardi, N.B, 2003, Murine Marrow-derived Mesenchymal Stem Cell: Isolation, in vitro Expansion, and Characterization, British J. Haem., I 23(4), 702-7II.

Purnomo, H., 20II, Kimia Komputasi: Molecular Docking PLANTS, Yogyakarta: Pustaka Pelajar.

Rachmady, R., 20I5, Aktivitas Sitotoksik Ekstrak Etanolik Kayu Secang (Caesalpinia sappan L.) terhadap Sel Kanker Payudara Bertarget Molekuler pada Reseptor HER-2, Essay, Universitas Gadjah Mada, Yogyakarta.

Shahidi, F., 1996, Natural Antioxidants: Chemistry, Health Effects, and Applications, Illionis: AOCS Press.

Shay, J.W., Wright, W.E. and Hayflick, L, 2000, His Limit and Cellular Aging, Nat. Rev. Mol. Cell Biol., I (I), 72-76.

Shlush, L.I., Itzkovitz, S., Cohen, A., Rutenberg, A., Berkovitz, R., Yehezkel, S., et al., 20II, Quantitative Digital in situ Senescenceassociated b-galactosidase Assay, BMC Cell Biol., I 2(I), 16.

Van Epps, H.L., 2005, How SLPI (secretory leukocyte protease inhibitor) soothes, J. Exp. Med., 202, 12.

Wang, Q., Zambetti, G.P. and Suttle, D.P., 1997, Inhibition of DNA Topoisomerase lla Gene Expressionby the p53 Tumor Suppressor, Mol. Cell Biol., I, 389-397. 